\title{
Why You Should Prefer Low Volatility ETFs
}

\section{Gil Cohen *}

\begin{abstract}
Low volatility ETFs have become popular in recent year because investors are starting to understand the advantages involved in investing in those ETFs compared to traditional index investment. In this research I have examined the performance of six popular low volatility ETFs, four of them invest in U.S stocks and the other two invest in other developed and emerging markets. Results have pointed out that not only five of the low volatility ETFs have exposed their investors to lower risk, four of them have also produced higher returns. The advantage of investing in low volatility ETFs is prominent in the U.S stock market. All three sizes of stocks categories (Large, Mid and Small Capitalization) low volatility ETFs have outperformed their indexes bench marks in terms of risk and returns. For the non U.S stock investing, while no advantage have been found for investing in low volatility ETFs for developed countries, significant lower risk was found for emerging markets.
\end{abstract}

Dr. Gil Cohen, Carmel Academic Center Business School, Haifa, Israel

Shar Palmer 4 Haifa, Israel. gilc@yvc.ac.il

Keywords: Low volatility, ETFs, Anomaly 


\section{Introduction}

In recent years low volatility stocks have become more and more popular among investor who seeks steady growth with as little as possible volatility. Achieving those goals along with a substantial diversification is possible throughout investing in the fast growing industry of low volatility ETFs. In addition to diversification, low volatility ETFs should offer lower risk than index investing strategy. These merits of low volatility ETFs are most welcome by investors, however, most of them associate low volatility stocks with low returns and for that reason they rather follow the major indexes. The perception that a portfolio that contains lower risk can achieve higher return than the index bench mark counter to the fundamental economic principle that risk is compensated with higher expected return and therefore ignored by some investors. Past researches have tried to explain why low volatility and low beta stocks have offered high average returns associated with lower risk than high volatility and high beta stocks. Ang et al. $(2006,2009)$ find that high volatility stocks have had "abysmally low returns" in U.S. samples and in international markets. Blitz and Vliet (2007) provide an analysis of the volatility anomaly across regions. Baker et al. (2011) have proposed explanation to the low volatility that combines the average investor's preference for risk and the typical institutional investor's mandate to maximize the ratio of excess returns and tracking error relative to a fixed benchmark without resorting to leverage. No extensive research has been conducted on low volatility ETFs since they started to develop in 2011and the number of such ETFs is growing ever since, insinuating that investors are realizing their benefits.

In the following research I examined the performance and risk of six major low volatility ETFs. Those it ETFs were chosen because they represent investment in varies segments of the U.S market and also Non U.S developed and emerging markets and because they are 
leading this segment in market value ${ }^{1}$. The chosen ETFs are: USMV (MSCI minimum volatility USA), SPLV (S\&P low volatility), XMLV (S\&P Mid Cap low volatility), XSLV (S\&P Small Cap low volatility), EFAV (MSCI min volatility EAFE) and EEMV (MSCI min volatility emerging markets). We start our analysis by calculating average monthly returns and standard deviations of our six low volatility ETFs and compare them to their bench marks. Than we apply the "market model" in order to examined "alphas" and "Betas" of our low volatility ETFS.

\section{2. $\underline{\text { Results }}$}

Table 1 summarizes the average monthly return for each ETF and its Bench mark ${ }^{2}$.

Table 1: Average Monthly Return of examined ETFs and their Benchmarks

\begin{tabular}{|c|c|c|c|c|c|c|}
\hline & USMV & SPLV & XMLV & XSLV & EFAV & EEMV \\
\hline Assets $^{1}$ & 14,747 & 7,638 & 530 & 437 & 7,345 & 3,840 \\
\hline Bench- Mark S\&P500 & S\&P500 & M.C 400 & R 2000 & EAFE & EEM \\
\hline $2016^{3}$ & 2.53 & 2.24 & 2.65 & 2.06 & 1.08 & 1.93 \\
& $(1.61)$ & $(1.61)$ & $(2.22)$ & $(1.90)$ & $(0.49)$ & $(2.39)$ \\
\hline 2015 & 0.405 & 0.23 & 0.25 & 0.15 & 0.16 & -1.37 \\
& $(-0.15)$ & $(-0.15)$ & $(-0.64)$ & $(-0.87)$ & $(-0.51)$ & $(1.71)$ \\
\hline 2014 & 1.50 & 1.34 & 1.44 & 1.03 & 0.96 & 0.95 \\
& $(0.96)$ & $(0.96)$ & $(0.79)$ & $(0.34)$ & $(0.00)$ & $(0.42)$ \\
\hline 2013 & 1.29 & 1.26 & 1.21 & 1.86 & 0.75 & -0.78 \\
& $(0.92)$ & $(0.92)$ & $(1.64)$ & $(2.03)$ & $(0.94)$ & $(-0.94)$ \\
\hline 2012 & 1.24 & 1.35 & N/A & N/A & 1.15 & 1.31 \\
& $(1.49)$ & $(1.49)$ & & & $(1.42)$ & $(0.66)$ \\
\hline Average & 1.22 & 1.18 & 1.25 & 1.15 & 0.79 & 0.25 \\
& $(0.93)$ & $(0.93)$ & $(0.81)$ & $(0.67)$ & $(0.46)$ & $(0.00)$ \\
\hline Stand Dev & 2.49 & 2.76 & 3.16 & 3.43 & 3.01 & 3.82 \\
\hline
\end{tabular}

\footnotetext{
1 More than 400 million dollar each.

${ }^{2}$ The averages monthly return of the Bench marks appear at Table1 in brackets.
} 


\begin{tabular}{|c|c|c|c|c|c|c|}
\hline & $(3.07)$ & $(3.07)$ & $(3.44)$ & $(4.18)$ & $(3.89)$ & $(4.73)$ \\
\hline Max & 5.98 & 6.87 & 7.64 & 9.34 & 7.23 & 9.22 \\
& $(8.29)$ & $(8.29)$ & $(8.31)$ & $(7.75)$ & $(7.82)$ & $(12.96)$ \\
\hline Min & -4.53 & -5.04 & -5.80 & -5.69 & -7.48 & -9.32 \\
& $(-6.26)$ & $(-6.26)$ & $(-5.78)$ & $(-8.84)$ & $(-11.14)$ & $(-10.70)$ \\
\hline Average/Stand & 0.49 & 0.42 & 0.39 & 0.33 & 0.26 & 0.06 \\
Dev & $(0.30)$ & $(0.30)$ & $(0.23)$ & $(0.16)$ & $(0.12)$ & $(0.00)$ \\
\hline
\end{tabular}

Notes: 1. Assets in Millions of U.S dollars as for 1.7.16. 2. M.C 400=Mid Cup 400 Index. R 2000= Russell 200 Small Cup Index. EAFE=MSCI EAFE Index composed of large-and mid-capitalization developed market equities, excluding the U.S. and Canada. $\mathrm{EEM}=\mathrm{MSCl}$ emerging markets Index. 3. Average monthly returns January until Jun 2016. 4. The average monthly return of the bench mark is shown in the brackets.

Table 1 results are quite astonishing, all examine ETFs have produced a higher average monthly return for the entire sample, along with a smaller risk. That means that any investor that wants to invest in indexes of the U.S capital market, large, Middle or Small market capitalization, is better off if he or she invest in their low volatility ETFs counterparts. Moreover, similar results have been demonstrated for large non U.S and Canada stocks or in emerging markets stocks. For large cup U.S stocks, the only year that the S\&P500 has outperformed the USMV and SPLV ETFs was 2012 while in all other examined years the opposite have occurred with much larger average monthly return differences. XMLV and XSLV have outperformed their bench marks Mid Cup 400 and Russell 200 indexes, for the years 2014-2016, failing to do so at 2013. Less impressive results have been found for the Non U.S stocks ETFs, on average as mentioned above investors are better off investing in the low volatility ETFs rather than investing in the Indexes however the excess return is unstable along the examined years.

Next I use weekly returns to test the low volatility ETFs for excess return over their bench marks using the market model (Equation 1) and summarize the results in Table 2 through 4 . 


$$
R_{E T F}-R f=\alpha+\beta\left(R_{B . M}-R f\right)
$$

Where: $R_{E T F}=$ weekly return of the low volatility ETF, $R_{B \cdot M}=$ weekly returns on the Bench Mark index, $R f=$ risk free rate.

Table 2: Large U.S Stocks Low Volatility ETFS Regressions Results

\begin{tabular}{|c|c|c|c|c|c|c|c|}
\hline ETF & Year & $\alpha$ & $\beta$ & $\mathrm{F}$ & $R^{2}$ & $\operatorname{adj} R^{2}$ & $N$ \\
\hline \multirow[t]{6}{*}{ USMV } & $\begin{array}{l}2012- \\
2016\end{array}$ & $\begin{array}{l}0.12^{*} \\
(3.27)\end{array}$ & $\begin{array}{c}0.72^{*} \\
(33.49)\end{array}$ & 1122 & 0.82 & 0.82 & 234 \\
\hline & 2016 & $\begin{array}{l}0.35^{*} \\
(2.70)\end{array}$ & $\begin{array}{c}0.70^{*} \\
(10.88) \\
\end{array}$ & 118 & 0.83 & 0.82 & 26 \\
\hline & 2015 & $\begin{array}{c}0.11 \\
(1.31)\end{array}$ & $\begin{array}{c}0.71^{*} \\
(16.27)\end{array}$ & 265 & 0.84 & 0.83 & 52 \\
\hline & 2014 & $\begin{array}{l}0.14^{*} \\
(2.61)\end{array}$ & $\begin{array}{c}0.75^{*} \\
(22.09)\end{array}$ & 488 & 0.90 & 0.90 & 52 \\
\hline & 2013 & $\begin{array}{c}0.00 \\
(0.026) \\
\end{array}$ & $\begin{array}{c}0.83^{*} \\
(12.28)\end{array}$ & 150 & 0.75 & 0.74 & 52 \\
\hline & 2012 & $\begin{array}{c}0.08 \\
(1.08)\end{array}$ & $\begin{array}{c}0.67^{*} \\
(16.84)\end{array}$ & 284 & 0.83 & 0.83 & 52 \\
\hline \multirow[t]{6}{*}{ SPLV } & $\begin{array}{l}2012- \\
2016\end{array}$ & $\begin{array}{l}0.18^{*} \\
(2.45)\end{array}$ & $\begin{array}{c}0.71^{*} \\
(25.12)\end{array}$ & 631 & 0.73 & 0.73 & 234 \\
\hline & 2016 & $\begin{array}{l}0.36^{*} \\
(2.18)\end{array}$ & $\begin{array}{l}0.70^{*} \\
(8.54)\end{array}$ & 73 & 0.75 & 0.74 & 26 \\
\hline & 2015 & $\begin{array}{c}0.08 \\
(0.82) \\
\end{array}$ & $\begin{array}{c}0.74^{*} \\
(13.95)\end{array}$ & 194 & 0.79 & 0.79 & 52 \\
\hline & 2014 & $\begin{array}{c}0.17^{*} \\
(2.134)\end{array}$ & $\begin{array}{c}0.71^{*} \\
(13.89)\end{array}$ & 193 & 0.79 & 0.79 & 52 \\
\hline & 2013 & $\begin{array}{c}-0.03 \\
(-0.27)\end{array}$ & $\begin{array}{l}0.84^{*} \\
(9.13)\end{array}$ & 84 & 0.62 & 0.61 & 52 \\
\hline & 2012 & $\begin{array}{c}0.09 \\
(1.06)\end{array}$ & $\begin{array}{c}0.60^{*} \\
(11.88)\end{array}$ & 141 & 0.74 & 0.73 & 52 \\
\hline
\end{tabular}

Notes: 1 . USMV= MSCI minimum volatility USA, SPLV= S\&P 500 low volatility.

2 . ${ }^{*}=$ statistically significant at $95 \%$ confidence level. 3 . The T statistics appears in the brackets.

Table 2 show that for the entire examined period (2012-2016) both large cap low volatility ETFs (USMV and SPLV) have achieved a positive statistically significant weekly abnormal return (0.12 and 0.18 respectively). Both ETFs have achieved those abnormal returns with 28-29 percent lower risk than the risk involved in investing in the 
S\&P5003. Analyzing the results year by year demonstrates that for both USMV and SPLV a positive significant abnormal return was achieved at 2014 and 2016 with a lower consistent significant lower risk for all the tested years. These results are consistent with the results summarized in Table 1 and have proven that an abnormal return measured by the well-known market model exists. Table 3 summarizes regressions results for Mid Cap and Small Cap U.S stocks low volatilities ETFs (XMLV and XSLV).

Table 3: Mid Cap and Small Cap U.S Stocks Low Volatility ETFS Regressions Results

\begin{tabular}{|c|c|c|c|c|c|c|c|}
\hline ETF & Year & $\alpha$ & $\beta$ & $F$ & $R^{2}$ & $\operatorname{adj} R^{2}$ & $\mathrm{~N}$ \\
\hline \multirow[t]{5}{*}{ XMLV } & $\begin{array}{l}2013- \\
2016 \\
\end{array}$ & $\begin{array}{l}0.16^{*} \\
(2.75) \\
\end{array}$ & $\begin{array}{c}0.74 * \\
(24.15) \\
\end{array}$ & 583 & 0.77 & 0.77 & 182 \\
\hline & 2016 & $\begin{array}{l}0.35^{*} \\
(2.22) \\
\end{array}$ & $\begin{array}{l}0.67^{*} \\
(8.84) \\
\end{array}$ & 78 & 0.77 & 0.76 & 26 \\
\hline & 2015 & $\begin{array}{c}0.14 \\
(1.29)\end{array}$ & $\begin{array}{c}0.73^{*} \\
(13.48)\end{array}$ & 182 & 0.78 & 0.78 & 52 \\
\hline & 2014 & $\begin{array}{l}0.23 * \\
(3.10) \\
\end{array}$ & $\begin{array}{c}0.72 * \\
(16.76) \\
\end{array}$ & 281 & 0.84 & 0.84 & 52 \\
\hline & 2013 & $\begin{array}{l}-0.03 \\
(-0.22)\end{array}$ & $\begin{array}{c}0.83 * \\
(10.32)\end{array}$ & 106 & 0.70 & 0.69 & 52 \\
\hline \multirow[t]{5}{*}{ XSLV } & $\begin{array}{l}2013- \\
2016\end{array}$ & $\begin{array}{l}0.16^{*} \\
(2.66) \\
\end{array}$ & $\begin{array}{c}0.69 * \\
(23.96) \\
\end{array}$ & 574 & 0.76 & 0.76 & 182 \\
\hline & 2016 & $\begin{array}{c}0.30 \\
(1.90) \\
\end{array}$ & $\begin{array}{l}0.63^{*} \\
(9.52) \\
\end{array}$ & 91 & 0.79 & 0.78 & 26 \\
\hline & 2015 & $\begin{array}{c}0.14 \\
(1.01)\end{array}$ & $\begin{array}{c}0.67^{*} \\
(11.48)\end{array}$ & 132 & 0.72 & 0.71 & 52 \\
\hline & 2014 & $\begin{array}{c}0.16 \\
(1.66) \\
\end{array}$ & $\begin{array}{c}0.70^{*} \\
(14.36)\end{array}$ & 206 & 0.80 & 0.80 & 52 \\
\hline & 2013 & $\begin{array}{c}0.08 \\
(0.77) \\
\end{array}$ & $\begin{array}{c}0.76^{*} \\
(12.29)\end{array}$ & 151 & 0.77 & 0.76 & 52 \\
\hline
\end{tabular}

Notes: 1 XMLV= S\&P Mid Cap low volatility, XSLV= S\&P Small Cap low volatility.

$2 . *=$ statistically significant at $95 \%$ confidence level. 3 . The T statistics appears in the brackets.

${ }^{3}$ The $\beta$ s are 0.72 and 0.71 for USMV and SPLV respectively. 
Table 3 shows that for both Mid and Small Cap stocks, low volatility ETFs have gained better returns for the entire sample with lower risk (26 and 31 percent less risk than their bench marks), making does ETFS superior to the indexes they follow. The XMLV has significantly outperformed its bench mark Mid Cap400 index at 2014 and 2016; however, the associated risk was much lower than the index for all years of the ETF existence. The XSLV has outperformed its bench mark Russel 2000 index for, as mentioned before, the entire period of time and nearly significant outperformance at 2016. Again the XSLV has offered its investors much lower risk for each of its existence years. Table 4 summarizes regressions results for $\mathrm{EAFE}^{4}$ and EEM ${ }^{5}$ stocks low volatilities ETFs (EFAV and EEMV).

Table 4: Non U.S EAFE and Emerging Markets Stocks Low Volatility ETFS Regressions Results

\begin{tabular}{|c|c|c|c|c|c|c|c|}
\hline ETF & Year & $\alpha$ & $\beta$ & $\mathrm{F}$ & $R^{2}$ & $\operatorname{adj} R^{2}$ & $\mathrm{~N}$ \\
\hline EFAV & $\begin{array}{l}2012- \\
2016\end{array}$ & $\begin{array}{c}0.18 \\
(1.95)\end{array}$ & $\begin{array}{c}-0.09 \\
(-1.30)\end{array}$ & 1.71 & 0.07 & 0.00 & 234 \\
\hline \multirow[t]{6}{*}{ EEMV } & $\begin{array}{l}2012- \\
2016\end{array}$ & $\begin{array}{c}0.06 \\
(1.60)\end{array}$ & $\begin{array}{c}0.73^{*} \\
(53.29)\end{array}$ & 2840 & 0.92 & 0.92 & 234 \\
\hline & 2016 & $\begin{array}{c}0.08 \\
(0.98)\end{array}$ & $\begin{array}{c}0.69 * \\
(25.29)\end{array}$ & 639 & 0.96 & 0.96 & 26 \\
\hline & 2015 & $\begin{array}{c}0.00 \\
(0.05)\end{array}$ & $\begin{array}{c}0.76^{*} \\
(36.34)\end{array}$ & 1320 & 0.96 & 0.96 & 52 \\
\hline & 2014 & $\begin{array}{c}0.06 \\
(1.07)\end{array}$ & $\begin{array}{c}0.69 * \\
(23.74)\end{array}$ & 564 & 0.91 & 0.91 & 52 \\
\hline & 2013 & $\begin{array}{c}0.04 \\
(0.41) \\
\end{array}$ & $\begin{array}{c}0.80 * \\
(20.11)\end{array}$ & 404 & 0.88 & 0.88 & 52 \\
\hline & 2012 & $\begin{array}{c}0.17 \\
(1.92)\end{array}$ & $\begin{array}{c}0.67^{*} \\
(18.16)\end{array}$ & 329 & 0.85 & 0.85 & 52 \\
\hline
\end{tabular}

Notes: $1 . \mathrm{EFAV}=\mathrm{MSCI}$ minimum volatility EAFE, EEMV= MSCI minimum volatility emerging markets. $2{ }^{*}=$ statistically significant at $95 \%$ confidence level. 3 . The $\mathrm{T}$ statistics appears in the brackets.

${ }^{4}$ EAFE is developed countries excluding U.S and Canada stocks index.

${ }^{5}$ EEM is emerging markets stocks index. 
Table 4 shows that there is no return or risk advantage investing in low volatility ETF (EFAV) over investing in MSCI Non U.S and Canada developed countries index (EAFE). This result was true for the entire examined period and also for all specific years ${ }^{6}$. On the other hand investing in low volatility EEMV ETF has proven fertile to investors since it produced a significant averaging $27 \%$ less risk than investing in MSCI emerging market index. No statistically significant abnormal return has been found although it was near significance at 2012.

\section{Summary and Conclusions}

Low volatility ETFs have become popular in recent year because investors are starting to understand the advantages involved in investing in those ETFs compared to traditional index investment. The industry of low volatility ETFs have started to emerge mostly at 2011 and is expanding ever since. In this research I have examined the performance of six popular low volatility ETFs, four of them invest in U.S stocks and the other two invest in other developed and emerging markets. First I have documented monthly average returns and standard deviations of those six ETFs and compared them to their Bench marks return. All six low volatility ETFs have proven better return to risk ratio than their bench marks. Second, I have used the market model in order to measure abnormal return and risk. Results have pointed out that not only five of the low volatility ETFs have exposed their investors to lower risk, four of them have also produced higher returns. The advantage of investing in low volatility ETFs is prominent in the U.S stock market. All three sizes of stocks categories (Large, Mid and Small Capitalization) low volatility ETFs have outperformed their indexes bench marks in terms of risk and returns. For the non U.S stock investing,

\footnotetext{
${ }^{6}$ The specific years do not appear at the table since they did not produce any statistically significant results.
} 
while no advantage have been found for investing in low volatility ETFs for developed countries, significant lower risk was found for emerging markets. 


\section{$\underline{\text { References }}$}

Ang, Andrew, R. Hodrick, Y. Xing, X. Zhang (2006). "The Cross-Section of Volatility and Expected Returns.” Journal of Finance, 61, pp. 259-299.

Ang A, R. Hodrick, Y. Xing, X. Zhang (2009), "High Idiosyncratic Volatility and Low Returns: International and Further U.S. Evidence”. Journal of Financial Economics, 91, pp. 123.

Baker, M. B Bradley and J. Wurgler (2011)," Benchmarks as Limits to Arbitrage: Understanding the Low-Volatility Anomaly". Financial Analysis Journal, 67,1.

Blitz, David, P. V. Vliet (2007), “The Volatility Effect: Lower Risk without Lower Return.” Journal of Portfolio Management 34, pp. 102-113. 